\title{
L-3,4-dihydroxyphenylalanine Accumulation in Faba Bean (Vicia faba L.) Tissues during Different Growth Stages
}

\author{
Shucheng Duan ${ }^{1,+}$, Soon Jae Kwon ${ }^{2,+} \oplus$, You Jin Lim ${ }^{1}$, Chan Saem Gil ${ }^{1}$, Chengwu Jin ${ }^{3}$ and Seok Hyun Eom ${ }^{1, *}$ \\ 1 Department of Horticultural Biotechnology, College of Life Sciences, Kyung Hee University, \\ Yongin 446-701, Korea; dsc97@khu.ac.kr (S.D.); yujn0213@khu.ac.kr (Y.J.L.); cskil@khu.ac.kr (C.S.G.) \\ 2 Advanced Radiation Technology Institute, Korea Atomic Energy Research Institute, Jeongeup 56212, Korea; \\ soonjaekwon@kaeri.re.kr \\ 3 School of Food Engineering, Ludong University, Yantai 264025, China; jinchwu@ldu.edu.cn \\ * Correspondence: se43@khu.ac.kr \\ + These authors are equally contributed as the first author.
}

Citation: Duan, S.; Kwon, S.J.; Lim, Y.J.; Gil, C.S.; Jin, C.; Eom, S.H.

L-3,4-dihydroxyphenylalanine

Accumulation in Faba Bean (Vicia faba L.) Tissues during Different Growth Stages. Agronomy 2021, 11, 502. https://doi.org/10.3390/agronomy 11030502

Academic Editor: Kirsten Brandt

Received: 8 February 2021

Accepted: 5 March 2021

Published: 8 March 2021

Publisher's Note: MDPI stays neutral with regard to jurisdictional claims in published maps and institutional affiliations.

Copyright: (c) 2021 by the authors. Licensee MDPI, Basel, Switzerland. This article is an open access article distributed under the terms and conditions of the Creative Commons Attribution (CC BY) license (https:// creativecommons.org/licenses/by/ $4.0 /)$.

\begin{abstract}
L-3,4-dihydroxyphenylalanine (L-dopa)-rich faba (Vicia faba L.) tissues are a potentially useful source for its pharmaceutical purpose, although the species contains health curious vicine and convicine in the seeds. We determined the contents of L-dopa, vicine, and convicine in different tissues of faba plants throughout the entire growth period. The three compounds accumulated in germinating sprouts and showed high contents at 8 days of germination, especially in the epicotyl containing $132.33 \mathrm{mg} \cdot \mathrm{g}^{-1} \mathrm{DW}$ of L-dopa, $19.81 \mathrm{mg} \cdot \mathrm{g}^{-1} \mathrm{DW}$ of vicine, and $10.38 \mathrm{mg} \cdot \mathrm{g}^{-1} \mathrm{DW}$ of convicine, respectively. We compared the contents of the three compounds among leaves of different ages in plants at different growth stages. The samples could be ranked, from highest to lowest content, ranging from 11.11 to $81.82 \mathrm{mg} \cdot \mathrm{g}^{-1} \mathrm{DW}$, as follows: new leaves $>$ young leaves $>$ old leaves; and vegetative $>$ flowering $>$ ripening. Vicine and convicine were not detected in leaves or flowers. The L-dopa content was high in flowers, especially young flower buds, ranging from 36.51 to $100.70 \mathrm{mg} \cdot \mathrm{g}^{-1} \mathrm{DW}$. In older flowers, the L-dopa content tended to decrease as the calyx and petal parts developed. In addition, the three compounds showed decreasing contents in pods, stems, and roots with increasing plant age. The results of this study provide information on the timing and extent of L-dopa, vicine, and convicine accumulation in different faba tissues, and indicate that various by-products, especially new/young leaves and flowers, are potential sources of natural L-dopa.
\end{abstract}

Keywords: faba bean; tissue; L-dopa; vicine; convicine; Parkinson's disease

\section{Introduction}

Faba bean, which belongs to the Fabaceae family, is the third most important legume after soybean and pea and is cultivated worldwide. Its dry seed production was ranked sixth among the cultivated grain legume crops in 2019 [1]. Because faba bean contains plentiful nutrients and is very cheap, the mature seeds are not only consumed as a staple food, but are also used as an additive [2,3] and as animal feed [4]. Because of the huge yield of faba bean, large amounts of by-products, such as stems, roots, flowers, leaves, and pod hulls are generated during its cultivation and seed harvesting. However, compared with the multipurpose seeds, the by-products are not commonly used and are usually disposed of as waste.

With an aim to improve the utilization of plant resources, many studies have explored the bioactivity of certain compounds and evaluated the potential of various faba plant tissues as food products [5-9]. The main active compound in mature faba beans, L-3,4dihydroxyphenylalanine (L-dopa), has been detected in every tissue of faba plants $[6,8,10,11]$. Since the last century, L-dopa has been considered as the gold standard for improving symptoms of Parkinson's disease (PD) [12]. Its other reported effects include improving 
eyesight, preventing hypertension, and reducing the risk of renal failure, and it also has antioxidant activity [13-17]. Several studies have reported that the L-dopa content is much lower in mature faba beans than in other tissues, especially flowers, leaves, and sprouts [18-20]. The L-dopa content in mature beans is significantly influenced by the genotype and environmental conditions $[8,10]$. The plant growth stage and degree of tissue development also affect L-dopa accumulation [10]. Most previous studies on L-dopa in faba have focused on several tissues of plants harvested at a specific period or L-dopa accumulation during seed germination and maturation. There is little information available about the changes in L-dopa contents in various tissues, especially leaves and flowers, among different developmental stages.

Faba beans also contain large amounts of the glucosidic aminopyrimidine derivatives, vicine and convicine [19]. On the one hand, they are regarded as anti-nutritional factors that cause favism in individuals who lack the enzyme glucose-6-phosphate dehydrogenase (G6PD) [8]. On the other hand, vicine and its hydrolysate divicine have been shown to exhibit anti-inflammatory effects [21]. Some previous studies have quantified vicine and convicine in seeds of different genotypes and focused on changes in their contents in seed germination or maturation [19,22-25]. Another study investigated changes in vicine and convicine contents in several plant tissues at different stages of pod development [26]. However, no previous study has analyzed the distribution of these substances in different faba plant tissues throughout all growth stages of the plant.

Considering the above, the aims of this study were as follows: (1) to determine the distribution of L-dopa, vicine, and convicine in different tissues; and (2) to analyze the accumulation patterns of each compound during all growth stages of faba plants. This is the first study to analyze the accumulation of L-dopa, vicine, and convicine in faba tissues over the entire growth period of the plant. The results will be useful for the development of strategies to fully utilize faba plant resources.

\section{Materials and Methods}

\subsection{Samples}

Faba bean seeds (Accession number: PI 469181, origin: Iran) were provided by the Advanced Radiation Technology Institute (Jeongeup, South Korea) [27]. The seed was the selection of the elite lines with high adaptability to autumn sowing. All seeds were soaked in distilled water for $24 \mathrm{~h}$ then rinsed three times with distilled water to remove the surface mucus. Healthy intact seeds were selected for these experiments. Each seed was planted in a pot filled with horticultural soil (Baroker, Seoulbio Co., Eumseong, Korea). The plants were grown in the greenhouse of Kyung Hee University $\left(37^{\circ} 14^{\prime} 36.0^{\prime \prime} \mathrm{N} 127^{\circ} 04^{\prime} 52.6^{\prime \prime} \mathrm{E}\right.$, Yongin, South Korea) during March, 2020 and relied on natural light. The temperature was set at $20 \pm 5^{\circ} \mathrm{C}$ during the faba growth.

According to the life cycle of the faba bean, its growth process can be divided arbitrarily into the sprout stage and the plant stage. For the sprout stage, seeds soaked for $24 \mathrm{~h}$ represented 1 day after germination, and the appearance of the first pair of leaves was considered to mark the end of the sprout stage. The sprout samples were harvested from 1 to 8 days after germination and at 12 days after germination. Plants were sampled at the seedling stage ( 15 days after germination), vegetative stage (30-35 days after germination), flowering stage (50-55 days after germination), and ripening stage (70-75 days after germination). Leaf samples (only new leaves were present at the seedling stage), stems, and roots were separately harvested at each of the four plant stages. Flower samples were collected from plants at the flowering stage. Fresh faba bean pods containing green seeds were harvested at four different developmental stages. A detailed description and the morphology of each sample are shown in Figure 1. Samples for each part and stage were collected from more than five individual faba plants. For sprout samples, ten randomly selected sprouts of each stage were used for analysis. 


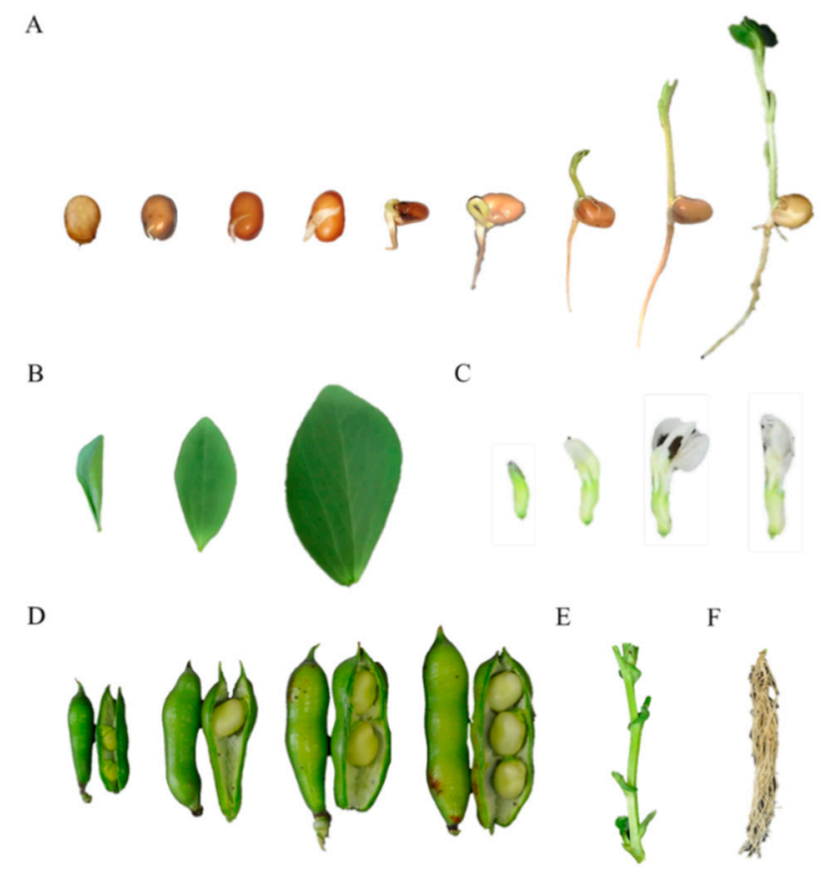

Figure 1. Morphology of faba plant tissues. (A) Faba bean sprouts from left to right: 1 to 8 and 12 days after germination, respectively; (B) Leaves from left to right are new (collected from the first node), young (collected from 2-4 nodes), and old leaves (collected from the base of the plant), respectively; (C) Flowers from left to right are flower bud (S1), young flower (S2), fully opened flower (S3), and senescent flower (S4), respectively; (D) Pods from left to right are S1 to S4, respectively, (E) Stem, and (F) Root.

\subsection{Analysis of L-dopa, Vicine, and Convicine Contents in Plant Tissues}

Samples of each part and stage were lyophilized at $-80{ }^{\circ} \mathrm{C}$ using a freeze dryer (IlshinBioBase. Co. Ltd., Dongducheon, Korea). The water contents in different tissues were as follows: $53.1 \%$ to $71.0 \%$ in sprouts; $83.7 \%$ to $89.6 \%$ in leaves; $86.7 \%$ to $89.8 \%$ in flowers; $81.5 \%$ to $86.3 \%$ in pod hulls; $72.4 \%$ to $82.3 \%$ in beans; $89.2 \%$ to $91.9 \%$ in stems; $92.5 \%$ to $95.6 \%$ in roots. The freeze-dried samples were ground using a mortar and sieved with a 100-mesh. Vicine, convicine, and L-dopa were extracted from plant tissues using the method of Vora et al. [28] with some modifications. The freeze-dried samples (5 mg) were extracted in $1 \mathrm{~mL} \mathrm{50 \%}(\mathrm{v} / \mathrm{v})$ aqueous methanol. The samples were treated with sonication for $30 \mathrm{~min}$ below $40^{\circ} \mathrm{C}$ to avoid thermal degradation by long time sonication [29]. The supernatant was obtained after centrifugation at $14,240 \times g$ for $15 \mathrm{~min}$. The extraction was performed in triplicate.

A $200-\mu \mathrm{L}$ aliquot of the supernatant was diluted with $800 \mu \mathrm{L}$ distilled water. After filtration through a $0.45-\mu \mathrm{m}$ membrane filter (Futecs Co., Ltd., Daejeon, South Korea), each sample was analyzed using a reversed-phase high-performance liquid chromatography (HPLC) (Waters 2695 Alliance HPLC; Waters Inc., Milford, MA, USA) equipped with an octadecylsilane column (Prontosil 120-5-C18-SH $5.0 \mu \mathrm{m}(250 \times 4.6 \mathrm{~mm}$; Bischoff, Leonberg, Germany)). The mobile phase consisted of solvent A (water with $0.3 \%$ formic acid) and solvent $\mathrm{B}$ (acetonitrile with $0.3 \%$ formic acid) applied with a linear gradient as follows: 0-9 $\mathrm{min}, 2 \% \mathrm{~B}$; 9-10 $\mathrm{min}, 2-80 \% \mathrm{~B} ; 10-14 \mathrm{~min}, 80 \% \mathrm{~B} ; 14-16 \mathrm{~min}, 2-80 \% \mathrm{~B}$; and $16-19 \mathrm{~min}$, $2 \% \mathrm{~B}$. The flow rate of the mobile phase was $0.8 \mathrm{~mL} / \mathrm{min}$, and the sample injection volume was $5 \mu \mathrm{L}$. Peaks were monitored at $280 \mathrm{~nm}$ using a Waters 996 photodiode array detector (Waters Inc.). The standards of L-dopa and vicine were purchased from Sigma-Aldrich (St. Louis, MO, USA) and Chemfaces (Wuhan, China), respectively. The quantitative analysis of convicine was calculated on the basis of vicine standard. 


\subsection{Statistical Analysis}

Statistical analyses were performed using one-way ANOVA following a normal distribution in SAS software (Enterprise Guide 7.1 version; SAS institute Inc., Cary, NC, USA). Significant differences among the treatments in these experiments were evaluated using Tukey's honestly significant difference (HSD) test at the level of $p<0.05$. All experiments (or treatments) were performed in triplicate.

\section{Results and Discussion}

\subsection{Accumulation of L-dopa, Vicine, and Convicine during Seed Germination}

The accumulation of L-dopa, vicine, and convicine during seed germination are shown in Table 1. The L-dopa content was low during the first few days after germination, but dramatically increased from $6 \mathrm{~d}$ when the primary plumule emerged and the root elongated (Figure 1A). However, the changes in vicine content (range, $9.74-11.38 \mathrm{mg} \cdot \mathrm{g}^{-1}$ DW) and convicine content (range, $4.01-5.00 \mathrm{mg} \cdot \mathrm{g}^{-1} \mathrm{DW}$ ) during this period were not as significant as that of L-dopa, and the proportions of the two compounds remained relatively similar. Consistent with those results, Goyoaga et al. [19] reported that L-dopa rapidly accumulated during seed germination while the total contents of pyrimidine glucosides remained unchanged.

Table 1. Changes in L-3,4-dihydroxyphenylalanine (L-dopa), vicine, and convicine contents in germinating faba beans.

\begin{tabular}{|c|c|c|c|}
\hline $\begin{array}{c}\text { Germination Time } \\
\text { (Days) }\end{array}$ & $\begin{array}{c}\text { L-dopa } \\
\left(\mathrm{mg} \cdot \mathrm{g}^{-1} \mathrm{DW}\right)\end{array}$ & $\begin{array}{c}\text { Vicine } \\
\left(\mathrm{mg} \cdot \mathrm{g}^{-1} \mathrm{DW}\right)\end{array}$ & $\begin{array}{c}\text { Convicine } \\
\left(\mathrm{mg} \cdot \mathrm{g}^{-1} \mathrm{DW}\right)\end{array}$ \\
\hline 1 & $0.43 \pm 0.00 \mathrm{~d}$ & $10.88 \pm 0.08 \mathrm{abc}$ & $4.43 \pm 0.08 \mathrm{abc}$ \\
\hline 2 & $0.47 \pm 0.01 \mathrm{~d}$ & $9.75 \pm 0.17 \mathrm{c}$ & $4.19 \pm 0.08 b c$ \\
\hline 3 & $0.51 \pm 0.03 \mathrm{~d}$ & $10.26 \pm 0.35 \mathrm{abc}$ & $4.01 \pm 0.16 c$ \\
\hline 4 & $0.70 \pm 0.01 \mathrm{~d}$ & $11.11 \pm 0.19 \mathrm{ab}$ & $4.19 \pm 0.11 b c$ \\
\hline 5 & $1.03 \pm 0.03 \mathrm{~d}$ & $10.85 \pm 0.05 \mathrm{abc}$ & $4.67 \pm 0.04 \mathrm{ab}$ \\
\hline 6 & $2.63 \pm 0.09 \mathrm{~cd}$ & $10.88 \pm 0.18 \mathrm{abc}$ & $4.72 \pm 0.07 \mathrm{ab}$ \\
\hline 7 & $4.50 \pm 0.07 c$ & $9.74 \pm 0.22 c$ & $4.18 \pm 0.98 \mathrm{bc}$ \\
\hline 8 & $11.11 \pm 0.32 b$ & $11.38 \pm 0.36 \mathrm{a}$ & $5.00 \pm 0.24 \mathrm{a}$ \\
\hline 12 & $16.87 \pm 1.58 \mathrm{a}$ & $10.07 \pm 0.44 \mathrm{bc}$ & $4.85 \pm 0.13 a$ \\
\hline
\end{tabular}

Values are averages with standard errors from triplicate experiments. Different letters within a column indicate significant differences at $p<0.05$ (Tukey's HSD test). DW indicates dry weight.

The morphology of sprouts changes at the end of the germination period (see Figure 1A). These changes are usually associated with the sprouts becoming harder and more fibrous and losing their fresh flavor [30]. Considering the food flavor and nutritional value of sprouts, those from $8 \mathrm{~d}$ after germination onwards can be considered a vegetable rich in L-dopa content (Figure 2A). To further distinguish where L-dopa, vicine, and convicine accumulated in the sprouts, we separated the 8-d sprouts into epicotyls, roots, and cotyledons. The contents of L-dopa and the sum of vicine and convicine were higher in epicotyls (L-dopa, $132.33 \mathrm{mg} \cdot \mathrm{g}^{-1} \mathrm{DW}$; vicine, $19.81 \mathrm{mg} \cdot \mathrm{g}^{-1} \mathrm{DW}$; convicine, $10.38 \mathrm{mg} \cdot \mathrm{g}^{-1} \mathrm{DW}$ ) than in roots (L-dopa, $59.03 \mathrm{mg} \cdot \mathrm{g}^{-1} \mathrm{DW}$; vicine, $21.59 \mathrm{mg} \cdot \mathrm{g}^{-1} \mathrm{DW}$; convicine, $7.23 \mathrm{mg} \cdot \mathrm{g}^{-1} \mathrm{DW}$ ) and cotyledons (L-dopa, $0.68 \mathrm{mg} \cdot \mathrm{g}^{-1} \mathrm{DW}$; vicine, $8.70 \mathrm{mg} \cdot \mathrm{g}^{-1}$; convicine, $3.42 \mathrm{mg} \cdot \mathrm{g}^{-1}$ ). Although it is known that the epicotyl is the direct source of L-dopa in sprouts [31], this is the first report of the different distribution patterns of vicine and convicine in cotyledons, epicotyls, and roots. The ratios between vicine and convicine contents was about 2 to 1 in epicotyls and about 3 to 1 in roots. A possible explanation of these results might be that vicine and convicine were synthesized in the testa and differently exported to the embryo during germination [32]. 


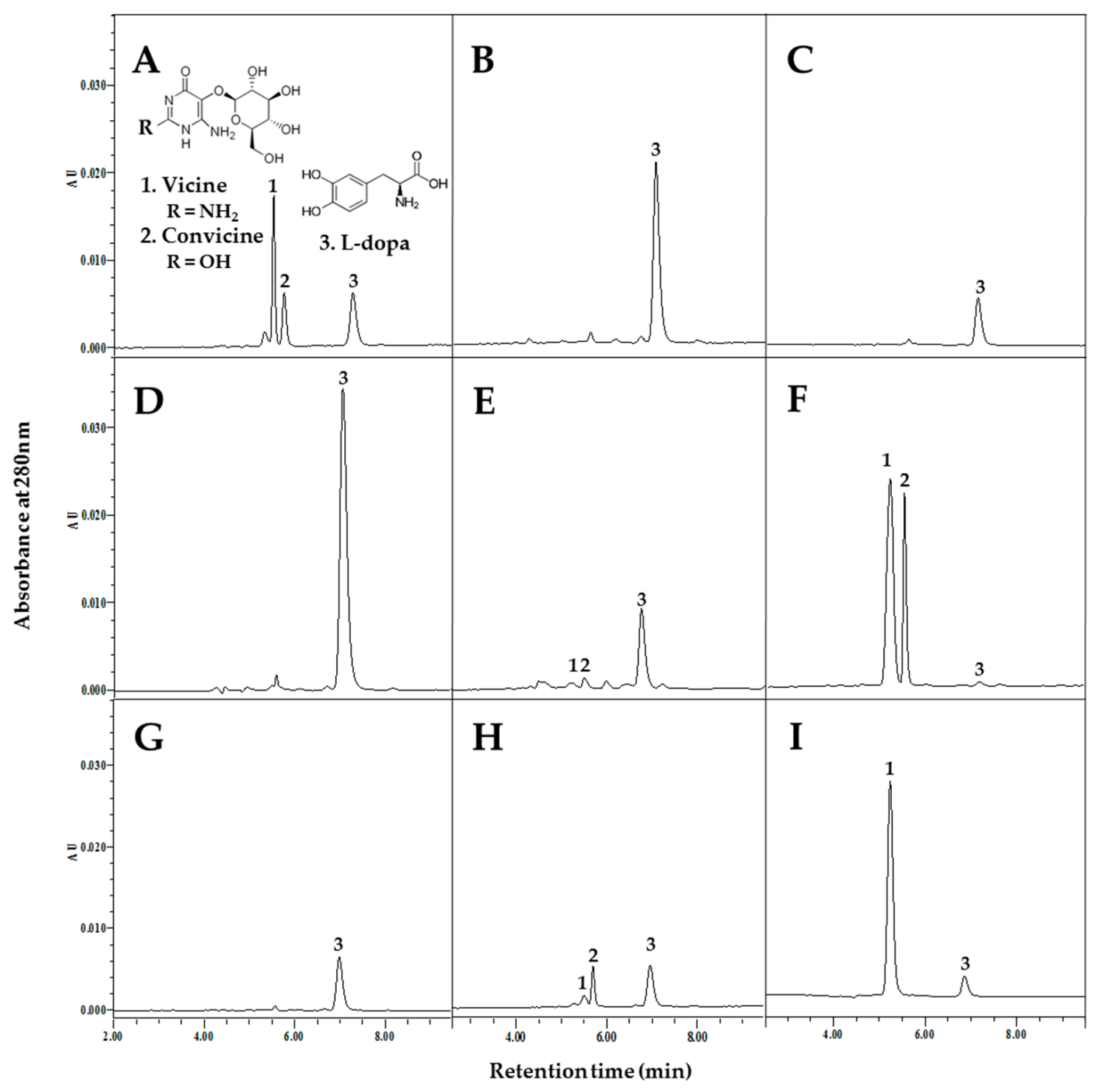

Figure 2. HPLC chromatograms of extracts from different faba bean tissues. (A) 8-day-old sprout; (B) New leaf at vegetative stage; (C) Old leaf at vegetative stage; (D) Flower bud; (E) Pod hull at S4 stage; (F) Bean at S4 stage; (G) Stem at ripening stage; (H) Root at ripening stage; (I) Standard peaks of vicine and L-dopa.

\subsection{Accumulation of L-dopa, Vicine, and Convicine in Leaves}

A previous study found that, among all faba plant tissues, the leaves had the highest L-dopa yield (content $\times$ dry matter) [11]. Faba bean leaves have attracted much attention because they could be used to develop functional foods with disease-prevention properties [6]. As shown in Figure 3, the L-dopa content differed among leaves at different stages of maturity, with the highest contents in new leaves (range, $35.69-81.82 \mathrm{mg} \cdot \mathrm{g}^{-1}$ DW), less in young leaves (range, $20.17-26.33 \mathrm{mg} \cdot \mathrm{g}^{-1} \mathrm{DW}$ ), and little in mature leaves. The L-dopa content was also significantly affected by plant stage and tended to decrease as the plants aged. The L-dopa content remained relatively stable in old leaves (range, $11.11-14.20 \mathrm{mg} \cdot \mathrm{g}^{-1} \mathrm{DW}$ ), slightly decreased at the flowering stage, and then remained at a low level at the ripening stage (Figure 3). In previous studies on the L-dopa content in faba leaves, a range of 28.19 to $39.82 \mathrm{mg} \cdot \mathrm{g}^{-1} \mathrm{DW}$ was detected among ten faba genotypes [33]. In a different study, a wider range of L-dopa content in leaves $\left(8.2-48.7 \mathrm{mg} \cdot \mathrm{g}^{-1} \mathrm{DW}\right)$ was detected among six faba bean varieties [18]. In the present study, the L-dopa content ranged from 11.11 to $81.82 \mathrm{mg} \cdot \mathrm{g}^{-1} \mathrm{DW}$ in faba bean leaves. Notably, previous studies mainly focused on the L-dopa content in the leaves of faba plants harvested at a specific stage. Our 
results show that L-dopa content is affected by leaf maturity and the plant growth stage. We found that the L-dopa content in new leaves was three times that in old leaves, and that in young leaves was twice that in old leaves. Similarly, the L-dopa content in new leaves was two times higher in plants at the seedling stage than in those at the ripening stage.

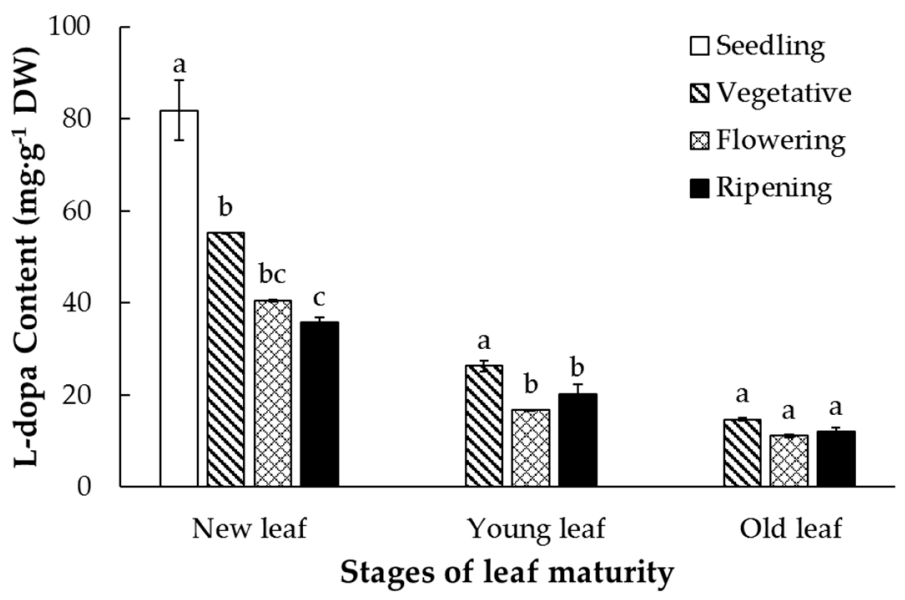

Figure 3. Changes in L-dopa content in leaves of faba plants at different stages of maturity. Different letters indicate significant differences at $p<0.05$ (Tukey's HSD test).

Whereas we detected significant changes in L-dopa content during the growth of faba leaves, we did not detect vicine or convicine in immature or mature plant leaves (Figure 2B,C). A similar result was reported by Ramsay et al. [26], who found that vicine and convicine were not present at detectable levels in leaf laminae. Although several studies have confirmed that L-dopa is present in faba bean leaves, the effects of maturity and growth period on L-dopa content has not been studied in-depth, and few studies have tried to detect vicine and convicine in leaves at different stages of maturity. Interestingly, faba leaves are regularly eaten in Italy, where they are considered as a substitute for spinach [6]. Therefore, based on our results and considering by-product utilization, we suggest that faba leaves (especially new leaves) are a good source of natural L-dopa. There is also the potential to use faba leaves to produce foods with a high natural L-dopa content.

\subsection{Accumulation of L-dopa, Vicine, and Convicine in Flowers}

The raceme of faba flowers is short and flowers open from bottom to top. To clarify the accumulation patterns of L-dopa, vicine, and convicine in faba flowers, the flowers were divided into four developmental stages (Figure 1C): flower bud (S1), young flower (S2), fully opened flower (S3), and senescent flower (S4) [34]. The accumulation of L-dopa in faba flowers was significantly influenced by the developmental stage (Figure 4A). The L-dopa content was higher in flower buds $\left(100.70 \mathrm{mg} \cdot \mathrm{g}^{-1} \mathrm{DW}\right)$ than in young flowers $\left(73.82 \mathrm{mg} \cdot \mathrm{g}^{-1}\right.$ DW), fully opened flowers (36.51 $\left.\mathrm{mg} \cdot \mathrm{g}^{-1} \mathrm{DW}\right)$, and senescent flowers $\left(46.89 \mathrm{mg} \cdot \mathrm{g}^{-1} \mathrm{DW}\right)$. Recent studies on faba flowers analyzed the L-dopa content in different cultivars harvested at a specific stage. Hu et al. [18] found that the L-dopa content ranged from 27.8 to $63.5 \mathrm{mg} \cdot \mathrm{g}^{-1} \mathrm{DW}$ among six cultivars. Zheng et al. [35] detected a range of L-dopa content in flowers from $0.53 \%$ to $10.63 \%$ (average, $4.48 \%$ ) among 97 germplasm faba accessions. Our results show that the L-dopa content is highest in the flower buds but decreases as the flowers open and bloom. Therefore, to obtain a high yield of L-dopa, the best time to harvest faba flowers may be before they are fully opened. 
A

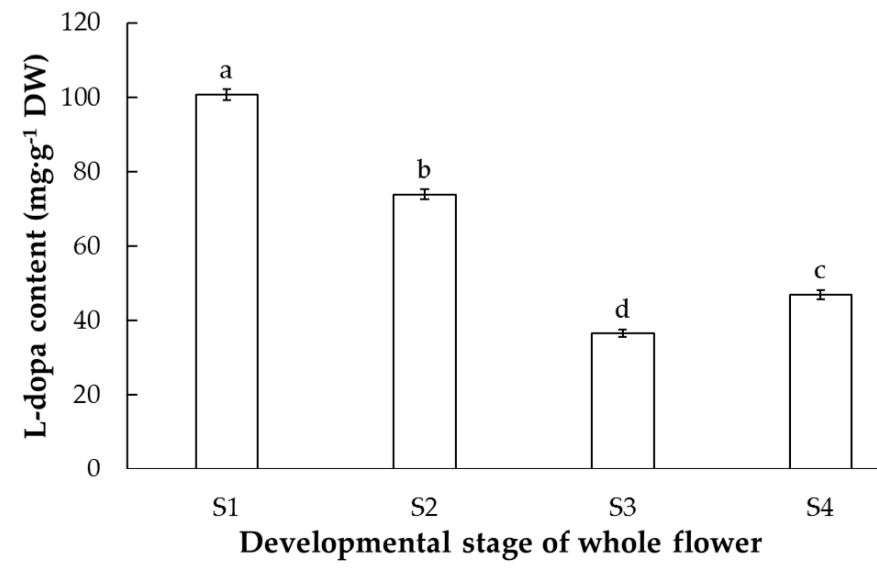

B

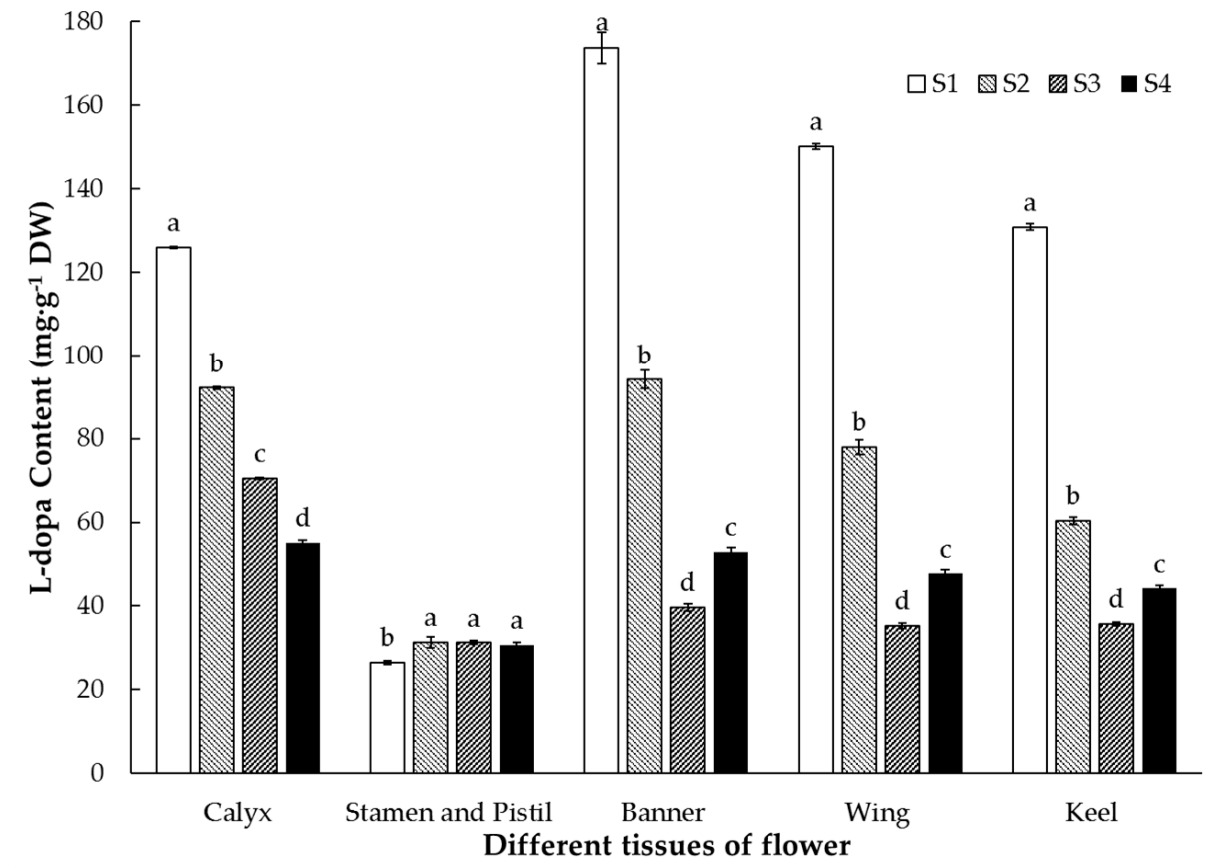

Figure 4. Changes in L-dopa content in (A) whole flowers at different developmental stages; and (B) different flower tissues. S1 to S4 indicate flower bud, unopened flower, fully opened flower, and senescent flower, respectively. DW, dry weight. Different letters above bars indicate significant differences at $p<0.05$ (Tukey's HSD test).

To further elucidate where L-dopa accumulates in faba flowers, we analyzed five different flower tissues. As shown in Figure 4B, L-dopa was detected in all flower tissues, with relatively higher contents in the calyx and petals (banner, wing, and keel) than in the stamen and pistil. As the plants approached physiological maturity, the L-dopa content in the calyx decreased (range, $55.09-125.87 \mathrm{mg} \cdot \mathrm{g}^{-1} \mathrm{DW}$ ), whereas that in the stamen and pistil (range, $26.50-31.31 \mathrm{mg} \cdot \mathrm{g}^{-1} \mathrm{DW}$ ) remained relatively low and stable. In the petals, banners had a higher L-dopa content (range, $39.65-173.70 \mathrm{mg} \cdot \mathrm{g}^{-1} \mathrm{DW}$ ) than did wings (range, 35.22-150.10 mg. ${ }^{-1} \mathrm{DW}$ ) and keels (range, 35.72-130.82 $\mathrm{mg} \cdot \mathrm{g}^{-1} \mathrm{DW}$ ) in each period. These patterns of L-dopa accumulation were consistent in petals (Figure 4B) and whole flowers (Figure 4A). Although the mechanism of L-dopa synthesis in faba flowers is still unclear, the changes in L-dopa content in whole flowers probably reflect the changes in petals. To the best of our knowledge, this is the first time that the distribution of L-dopa among different flower tissues and among flowers at different stages of development has been analyzed. 
It is valuable information that faba flowers contain a large amount of L-dopa but no vicine or convicine (Figure 2D). L-dopa is used to improve the symptoms of PD, while vicine and convicine are the main compounds that cause favism. However, another study detected L-dopa and vicine in faba bean flowers and pollen, as well as in honey produced from these sources [36]. These different findings may help to explain why inhaling faba bean flower pollen caused favism symptoms in some cases but not in others [37]. While previous studies have focused on the L-dopa content in flowers, few have compared vicine and convicine contents among different faba cultivars. Plant breeding strategies may focus on producing faba varieties with flowers with high L-dopa contents and no vicine and convicine as resources for producing functional foods that prevent PD without causing favism.

\subsection{Accumulation of L-dopa, Vicine, and Convicine in Faba Bean Pods}

In some countries, faba beans are eaten as a vegetable while still young and tender (Figure 1D) [8]. We determined the L-dopa content in the green pods at different developmental stages and detected high L-dopa contents (range, $13.32-39.44 \mathrm{mg} \cdot \mathrm{g}^{-1} \mathrm{DW}$ ) in young pod hulls, along with trace amounts of vicine and convicine (Figure 5). In contrast, immature beans tended to accumulate vicine and convicine instead of L-dopa $\left(<0.60 \mathrm{mg} \cdot \mathrm{g}^{-1}\right.$ DW) (Figure 5). Overall, the contents of all three compounds tended to decrease as the pods matured. Consistent with this, Burbano et al. [25] reported that the contents of Ldopa, vicine, and convicine in pods decreased as the dry matter content increased. The distribution of L-dopa in green faba bean pods has been widely studied. Topal et al. [38] found that the L-dopa content in green pods ranged from 4.16 to $54.29 \mathrm{mg} \mathrm{kg}^{-1}$ among 22 faba bean genotypes, while Ryu et al. [33] detected a range of 16.31 to $79.58 \mathrm{mg} \cdot \mathrm{g}^{-1} \mathrm{DW}$ among ten genotypes. In our study, the L-dopa content was three times higher in pod hulls at S1 than at S4. This result indicates that the harvest period is as important as genotype in terms of L-dopa content. The accumulations of L-dopa, vicine, and convicine in mature beans have also been widely studied. Purves et al. [23] determined the concentrations of vicine (range, $0.13-10.80 \mathrm{mg} \cdot \mathrm{g}^{-1}, \mathrm{DW}$ ), convicine (range, $0.011-5.24 \mathrm{mg} \cdot \mathrm{g}^{-1}, \mathrm{DW}$ ), and L-dopa (range, $0.09-1.19 \mathrm{mg} \cdot \mathrm{g}^{-1}$, DW) in 42 faba bean genotypes. Other studies exhibited that L-dopa contents in faba grains were varied from 0.72 to $15.69 \mathrm{mg} \cdot \mathrm{g}^{-1}$, DW [33]. Mature beans contained only small amounts of L-dopa in most cultivars $[10,23,29,33]$, while immature seeds tended to contain more beneficial substances such as L-dopa, polyphenols, carotenoids, and vitamin C [39]. In summary, considering the high content of L-dopa and other valuable compounds in green pods, we suggest that faba beans could be harvested earlier and used as a potential substitute for other fresh legume vegetables, such as soybean and green peas. 
A

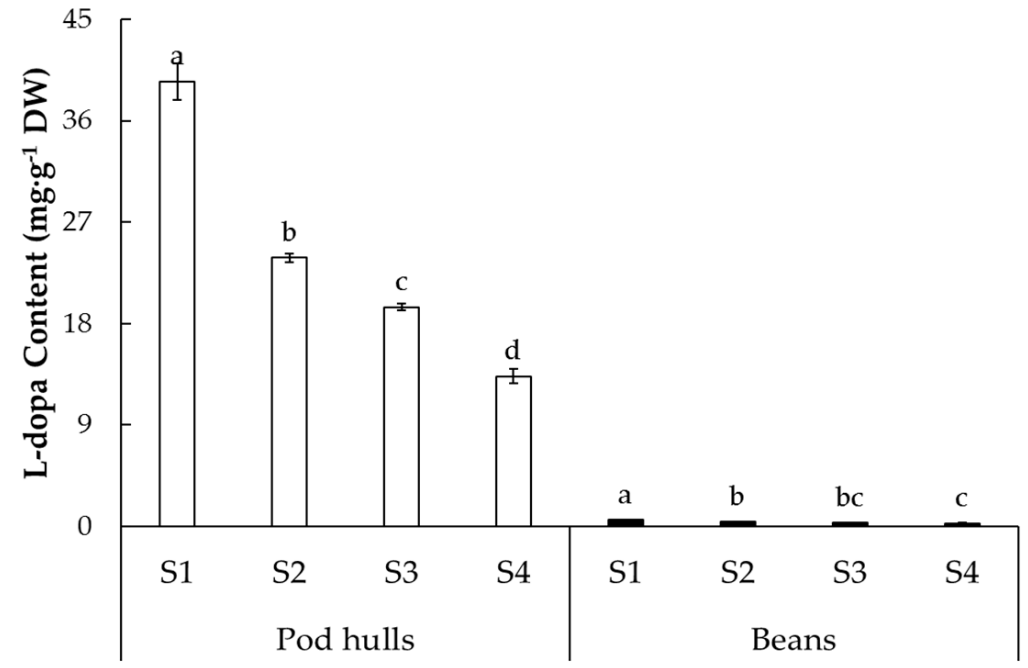

B

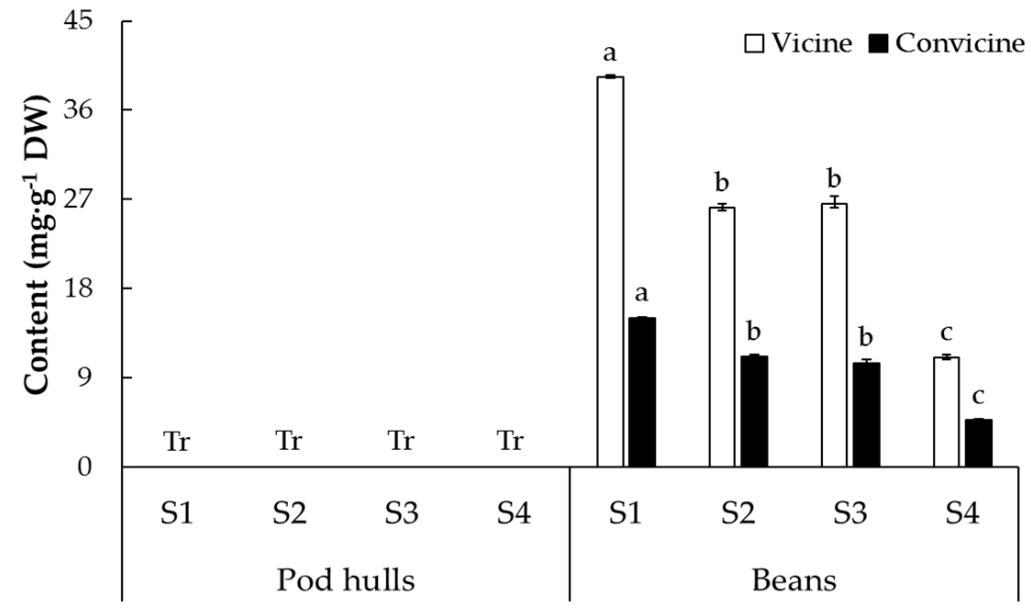

Figure 5. Contents of (A) L-dopa and (B) vicine and convicine in pod hulls and beans at different development stages. DW, dry weight. Tr, trace amount. Different letters within the same color column indicate significant differences at $p<0.05$ (Tukey's HSD test).

\subsection{Accumulation of L-dopa, Vicine, and Convicine in Other Faba Organs}

Table 2 shows the accumulation patterns of L-dopa, vicine, and convicine in stems and roots during the growth and development of faba plants. The L-dopa content was highest in seedling-stage stems $\left(71.48 \mathrm{mg} \cdot \mathrm{g}^{-1} \mathrm{DW}\right)$ and roots $\left(55.15 \mathrm{mg} \cdot \mathrm{g}^{-1} \mathrm{DW}\right)$ and much lower in those organs at the ripening stage $\left(<13 \mathrm{mg} \cdot \mathrm{g}^{-1} \mathrm{DW}\right.$ and $9 \mathrm{mg} \cdot \mathrm{g}^{-1} \mathrm{DW}$, respectively). Similar accumulation patterns were detected for vicine and convicine. During the physiological development of the plants, the contents of L-dopa, vicine, and convicine decreased in stems and roots (Table 2). Stems contained more vicine than convicine, whereas roots contained more convicine than vicine. Neither vicine nor convicine were detected in stems after the vegetative stage (Figure 2G). 
Table 2. L-dopa, vicine, and convicine contents in stems and roots during the four growth stages of faba bean plants.

\begin{tabular}{|c|c|c|c|c|}
\hline Plant Part & Stage of Plant & $\begin{array}{c}\text { L-dopa } \\
\left(\mathrm{mg} \cdot \mathrm{g}^{-1} \mathrm{DW}\right)\end{array}$ & $\begin{array}{c}\text { Vicine } \\
\left(\mathrm{mg} \cdot \mathrm{g}^{-1} \mathrm{DW}\right)\end{array}$ & $\begin{array}{c}\text { Convicine } \\
\left(\mathrm{mg} \cdot \mathrm{g}^{-1} \mathrm{DW}\right)\end{array}$ \\
\hline \multirow{4}{*}{ Stem } & Seedling & $71.48 \pm 1.04 \mathrm{a}$ & $9.59 \pm 0.28 \mathrm{a}$ & $7.92 \pm 0.22 \mathrm{a}$ \\
\hline & Vegetative & $17.67 \pm 0.06 b$ & $1.41 \pm 0.08 \mathrm{~b}$ & $0.75 \pm 0.05 b$ \\
\hline & Flowering & $6.81 \pm 0.24 \mathrm{~d}$ & N.D. & N.D. \\
\hline & Ripening & $12.92 \pm 0.23 c$ & N.D. & N.D. \\
\hline \multirow{4}{*}{ Root } & Seedling & $55.15 \pm 0.66 \mathrm{a}$ & $3.81 \pm 0.03 \mathrm{a}$ & $8.90 \pm 0.17 \mathrm{a}$ \\
\hline & Vegetative & $28.82 \pm 0.24 b$ & $2.67 \pm 0.01 b$ & $5.81 \pm 0.15 b$ \\
\hline & Flowering & $9.61 \pm 0.42 c$ & $0.67 \pm 0.02 \mathrm{~d}$ & $2.01 \pm 0.02 \mathrm{~d}$ \\
\hline & Ripening & $8.73 \pm 0.69 c$ & $1.37 \pm 0.06 \mathrm{c}$ & $3.18 \pm 0.69 c$ \\
\hline
\end{tabular}

Values indicate averages with standard errors from triplicate experiments. Different letters within a column indicate significant differences at $p<0.05$ (Tukey's HSD test). DW indicates dry weight. N.D. means not detected.

Previous studies mainly focused on differences in L-dopa, vicine, and convicine contents among tissues at a particular stage of pod development. For example, Etemadi et al. [11] found that the L-dopa content was higher in the roots than in the stems in plants harvested at physiological maturity, and they also investigated the partitioning of L-dopa in various organs of faba [10]. Ramsay et al. [26] found that the vicine and convicine contents in roots were largely unchanged during seed development but were not detected in stems after the early seed development stage. L-dopa, vicine, and convicine are valuable compounds that are present in faba stems and roots. However, they are often studied separately. Both the genotype and growth environment can affect the accumulation of each compound. Our results show that L-dopa, vicine, and convicine accumulation patterns are similar in roots and stems during the entire growth stage of the plant.

Faba stems and roots are by-products that are produced in large quantities during the cultivation of faba beans. However, they are usually discarded as waste. This not only wastes natural L-dopa resources but also affects the utilization of land resources. Our results indicate that faba stems and roots could have potential applications in the development of foods or drugs containing natural L-dopa. In addition, because L-dopa also functions as an allelochemical, by-products with high L-dopa contents could potentially be used to develop growth regulators, herbicides, insecticides, and antimicrobial crop protection products [31].

\section{Conclusions}

This is the first study to monitor the accumulation of L-dopa, vicine, and convicine in faba tissues during the entire growth period. Overall, L-dopa was detected in all faba tissues, whereas vicine and convicine were mainly detected in sprouts, immature seeds, and roots and stems (at early growth stages). For faba bean sprouts, a suitable germination time is an important factor in seed nutritional quality. The epicotyls and roots of sprouts are direct sources of not only L-dopa but also vicine and convicine. The relatively harmful compounds vicine and convicine were detected in neither immature nor mature plant leaves. Faba leaves can be regarded as a good daily source of natural L-dopa. Our results show that leaf maturity and plant growth stage are important factors in terms of L-dopa content. The flowers are another potential L-dopa resource. Our results show that flowers contained decreasing L-dopa contents as they developed but no vicine and convicine. Analyses of the distribution of L-dopa among flower tissues indicated that the changes in L-dopa content in whole flowers was mainly due to changes in the petals. Pod hulls account for about $75 \%$ of the total faba bean yield [8]. We suggest that this L-dopa-rich by-product can be eaten as a vegetable. Roots and stems are also by-products rich in L-dopa. We did not detect vicine and convicine in stems after the vegetative stage, suggesting that stems may be a source of L-dopa for natural drugs. In summary, a suitable germination time (8 days) is important for sprout nutrition and flavor [30]. Plant materials at early 
growth stages and young tissues are good sources of L-dopa. This study provides reference information for the utilization of various tissues of faba as sources of L-dopa.

Author Contributions: Conceptualization, S.H.E. and S.J.K.; methodology, S.D., C.J. and S.H.E.; software, S.D.; validation, S.H.E., S.J.K., C.J. and S.D.; formal analysis, S.D.; investigation, S.D. and C.S.G.; resources, S.-J.K.; data curation, S.D. and Y.J.L.; writing-original draft preparation, S.D. and S.J.K.; writing-review and editing, S.H.E. All authors have read and agreed to the published version of the manuscript.

Funding: This work was supported by Radiation Technology R\&D program (NRF-2017M2A2A6A05018538) through the National Research Foundation of Korea funded by the Ministry of Science and ICT. This work was also supported by the National Research Foundation of Korea (NRF) grant funded by the Korea government (MSIT) (NO. NRF-2019R1A2C1009623).

Institutional Review Board Statement: Not applicable.

Informed Consent Statement: Not applicable.

Data Availability Statement: Not applicable.

Conflicts of Interest: The authors declare no conflict of interest.

\section{References}

1. Food and Agriculture Organization of the United Nations. FAOSTAT. Available online: http://faostat.fao.org (accessed on 2 March 2020).

2. Kumar, A.; Nidhi; Prasad, N.; Sinha, S.K. Nutritional and antinutritional attributes of faba bean (Vicia faba L.) germplasms growing in Bihar, India. Physiol. Mol. Biol. Plants 2015, 21, 159-162. [CrossRef] [PubMed]

3. Jiang, Z.Q.; Pulkkinen, M.; Wang, Y.J.; Lampi, A.M.; Stoddard, F.L.; Salovaara, H.; Piironen, V.; Sontag-Strohm, T. Faba bean flavour and technological property improvement by thermal pre-treatments. LWT-Food Sci. Technol. 2016, 68, 295-305. [CrossRef]

4. Kwon, S.-J.; Kim, D.-G.; Kim, J.M.; Kang, K.-Y.; Lee, M.-K.; Hong, M.J.; Kim, J.-B.; Eom, S.H.; Kang, S.-Y.; Ha, B.-K.; et al. Phytochemical compounds and antioxidant activity in the grain of selected faba bean (Vicia faba) genotypes. Plant Breed. Biotech. 2018, 6, 65-73. [CrossRef]

5. Okumura, K.; Hosoya, T.; Kawarazaki, K.; Izawa, N.; Kumazawa, S. Antioxidant activity of phenolic compounds from Fava bean sprouts. J. Food Sci. 2016, 81, 1394-1398. [CrossRef]

6. Renna, M.; Signore, A.; Paradiso, V.M.; Santamaria, P. Faba greens, globe artichoke's offshoots, crenate broomrape and summer squash greens: Unconventional vegetables of Puglia (southern Italy) with good quality traits. Front. Plant Sci. $2018,9,378$. [CrossRef]

7. Allam, A.; Nafady, A.; Khedr, A.I.M.; Nakagawa, T.; Shimizu, K. Potential activities for constituents from Vicia faba. Trends Phytochem. Res. 2018, 2, 21-26.

8. Renna, M.; De Cillis, F.; Leoni, B.; Acciardi, E.; Santamaria, P. From by-product to unconventional vegetable: Preliminary evaluation of fresh fava hulls highlights richness in L-dopa and low content of anti-nutritional factor. Foods 2020, 9, 159. [CrossRef]

9. Neugart, S.; Rohn, S.; Schreiner, M. Identification of complex, naturally occurring flavonoid glycosides in Vicia faba and Pisum Sativum leaves by HPLC-DAD-ESI-MS ${ }^{n}$ and the genotypic effect on their flavonoid profile. Food Res. Int. 2015, 76, 114-121. [CrossRef]

10. Etemadi, F.; Hashemi, M.; Autio, W.R.; Mangan, F.X.; Zandvakili, O. Yield and accumulation trend of biomass and L-DOPA in different parts of eight faba bean cultivars. Crop Sci. 2018, 58, 2020-2028. [CrossRef]

11. Etemadi, F.; Hashemi, M.; Randhir, R.; ZandVakili, O.; Ebadi, A. Accumulation of L-DOPA in various organs of faba bean and influence of drought, nitrogen stress, and processing methods on L-DOPA yield. Crop J. 2018, 6, 426-434. [CrossRef]

12. Poewe, W.; Antonini, A.; Zijlmans, J.C.; Burkhard, P.R.; Vingerhoets, F. Levodopa in the treatment of Parkinson's disease: An old drug still going strong. Clin. Interv. Aging 2010, 5, 229-238. [CrossRef] [PubMed]

13. Min, K.; Park, K.; Park, D.-H.; Yoo, Y.J. Overview on the biotechnological production of L-DOPA. Appl. Microbiol. Biotechnol. 2015, 99, 575-584. [CrossRef] [PubMed]

14. Thomson, K.; Karouta, C.; Morgan, I.; Ashby, R. Effectiveness and safety of topical levodopa in a chick model of myopia. Sci. Rep. 2019, 9, 18345. [CrossRef]

15. Saito, I.; Kawabe, H.; Hasegawa, C.; Iwaida, Y.; Yamakawa, H.; Saruta, T.; Takeshita, E.; Nagano, S.; Sekihara, T. Effect of L-dopa in young patients with hypertension. Angiology 1991, 42, 691-695. [CrossRef]

16. Zech, P.; Collard, M.; Guey, A.; Plantier, J.; Beruard, M.; Berthoux, F.; Pinet, A.; Traeger, J. Renal hemodynamic response to L-dopa during acute renal failure in Man. Biomedicine 1975, 23, 456-460. [PubMed]

17. Rabey, J.M.; Vered, Y.; Shabtai, H.; Graff, E.; Korczyn, A.D. Improvement of parkinsonian features correlate with high plasma levodopa values after broad bean (Vicia faba) consumption. J. Neurol. Neurosurg. Psychiatry 1992, 55, 725-727. [CrossRef] 
18. Hu, J.; Kwon, S.-J.; Park, J.-J.; Landry, E.; Mattinson, D.S.; Gang, D.R. LC-MS determination of L-DOPA concentration in the leaf and flower tissues of six faba bean (Vicia faba L.) lines with common and rare flower colors. Funct. Foods Health Dis. 2015, 5, 243-250. [CrossRef]

19. Goyoaga, C.; Burbano, C.; Cuadrado, C.; Varela, A.; Guillamón, E.; Pedrosa, M.M.; Muzquiz, M. Content and distribution of vicine, convicine and L-DOPA during germination and seedling growth of two Vicia faba L. varieties. Eur. Food Res. Technol. 2008, 227, 1537-1542. [CrossRef]

20. Geng, G. Analysis on content of L-DOPA in various tissues of horsebean in field production. North. Hortic. 2012, 2, $26-27$.

21. Hussein, M.A. Anti-inflammatory effect of natural heterocycle glucoside vicine obtained from Vicia faba L. its aglucone (divicine) their effect on some oxidative stress biomarkers in Albino rats. Free Radic. Antioxid. 2012, 2, 44-54. [CrossRef]

22. Cardador-Martínez, A.; Maya-Ocaña, K.; Ortiz-Moreno, A.; Herrera-Cabrera, B.E.; Dávila-Ortiz, G.; Múzquiz, M.; Martín-Pedrosa, M.; Burbano, C.; Cuadrado, C.; Jiménez-Martínez, C. Effect of roasting and boiling on the content of vicine, convicine and L-3,4-Dihydroxyphenylalanine in Vicia faba L. J. Food Qual. 2012, 35, 419-428. [CrossRef]

23. Purves, R.W.; Zhang, H.; Khazaei, H.; Vandenberg, A. Rapid analysis of medically relevant compounds in faba bean seeds using FAIMS and mass spectrometry. Int. J. Ion Mobil. Spec. 2017, 20, 1-11. [CrossRef]

24. Purves, R.W.; Khazaei, H.; Vandenberg, A. Quantification of vicine and convicine in faba bean seeds using hydrophilic interaction liquid chromatography. Food Chem. 2018, 240, 1137-1145. [CrossRef]

25. Burbano, C.; Cuadrado, C.; Muzquiz, M.; Cubero, J.I. Variation of favism-inducing factors (vicine, convicine and L-DOPA) during pod development in Vicia faba L. Plant Foods Hum. Nutr. 1995, 47, 265-275. [CrossRef]

26. Ramsay, G.; Griffiths, D.W. Accumulation of vicine and convicine in vicia faba and V. narbonensis. Phytochemistry 1996, $42,63-67$. [CrossRef]

27. Lee, M.-K.; Kim, D.-G.; Kim, J.M.; Ryu, J.; Eom, S.H.; Hong, M.J.; Hong, M.J.; Jang, Y.E.; Ha, B.-K.; Kwon, S.-J. Selection of the elite lines with high adaptability to autumn sowing of South Korea in faba bean. Plant Breed. Biotech. 2018, 6, 57-64. [CrossRef]

28. Vora, R.; Joshi, A.N.; Joshi, N.C. Comparison of extraction efficiency of various methods to extract L-DOPA from Mucuna pruriens (L.) DC. Int. J. Bioassays 2017, 6, 5343. [CrossRef]

29. Polanowska, K.; Łukasik, R.; Kuligowski, M.; Nowak, J. Development of a sustainable, simple, and robust method for efficient 1-DOPA extraction. Molecules 2019, 24, 2325. [CrossRef]

30. Labaneiah, M.E.O.; Luh, B.S. Changes of starch, crude fiber, and oligosaccharides in germinating dry beans. Cereal Chem. 1981, 58, 135-138.

31. Oviedo-Silva, C.; Elso-Freudenberg, M.; Aranda-Bustos, M. L-DOPA trends in different tissues at early stages of Vicia faba growth: Effect of tyrosine treatment. Appl. Sci. 2018, 8, 2431. [CrossRef]

32. Björnsdotter, E.; Nadzieja, M.; Chang, W.; Escobar-Herrera, L.; Mancinotti, D.; Angra, D.; Khazaei, H.; Crocoll, C.; Vandenberg, A.; Stoddard, F.L.; et al. VC1 catalyzes a key step in the biosynthesis of vicine from GTP in faba bean. bioRxiv 2020. [CrossRef]

33. Ryu, J.; Kim, D.-G.; Lee, M.-K.; Kim, J.M.; Hong, M.J.; Kang, K.-Y.; Eom, S.H.; Kang, S.-Y.; Kim, J.-B.; Kwon, S.-J. Fatty acid composition, isoflavone and L-3,4-dihydroxyphenylalanine (L-dopa) contents in different parts of faba bean (Vicia faba) genotypes. Plant Breed. Biotech. 2017, 5, 314-324. [CrossRef]

34. Zhou, C.; Sun, C.; Chen, K.; Li, X. Flavonoids, phenolics, and antioxidant capacity in the flower of Eriobotrya japonica Lindl. Int. J. Mol. Sci. 2011, 12, 2935-2945. [CrossRef] [PubMed]

35. Zheng, K.-B.; Xu, X.-Y.; Qiu, S.-L.; Li, A.-P. Study on L-dopa content in faba bean flowers. Legume Res. 2016, 39, 931-934.

36. Topal, N.; Bulduk, I.; Mut, Z.; Bozodlu, H.; Tosun, Y.K. Flowers, pollen and honey for use in the treatment of Parkinson's disease. Rev. Chim. 2020, 71, 308-319. [CrossRef]

37. Belsey, M.A. The epidemiology of favism. Bull. World Health Organ. 1973, 48, 1-13.

38. Topal, N.; Bozoğlu, H. Determination of L-dopa (L-3, 4-dihydroxyphenylalanine) content of some faba bean (Vicia faba L.) genotypes. J. Agric. Sci. 2016, 22, 145-151. [CrossRef]

39. De Cillis, F.; Leoni, B.; Massaro, M.; Renna, M.; Santamaria, P. Yield and quality of faba bean (Vicia faba L. var. major) genotypes as a vegetable for fresh consumption: A comparison between Italian landraces and commercial varieties. Agriculture 2019, 9, 253. [CrossRef] 